\title{
COHERENT ADDITION OF ORTHOGONALLY POLARIZED FIBRE LASERS WITH HIGH COMBINING EFFICIENCY
}

\author{
K. Regelskis, N. Gavrilinas, R. Trusovas, and G. Račiukaitis \\ Institute of Physics, Center for Physical Sciences and Technology, Savanoriu 231, LT-02300 Vilnius, Lithuania \\ E-mail: regelskis@ar.fi.lt
}

Received 11 May 2010; revised 3 June 2010; accepted 17 June 2010

\begin{abstract}
We demonstrate a free-space combining of two orthogonally polarized fibre lasers by using polarization selective loss and a common adjustable output coupler. The lasers were locked coherently in phase in such a way that the combined beam experienced a minimal cavity loss. In contrast to a conventional coherent locking scheme due to interference, when combined beams are of the same polarization state, this scheme has the advantage of easy tunability in the output power, providing high combining efficiency even when the power of both fibre lasers is highly imbalanced. A high combining efficiency of the fibre laser beams was achieved by the coherent polarization locking method. In comparing the output power of both free-running fibre lasers with the output power in coherently locked state, it was observed that the combining efficiency exceeded $100 \%$. The output power enhancement was due to the difference in optimal feedback conditions for separate free-running lasers. One laser was additionally seeded from the second laser, and the seeding originated the higher output power of coherently added lasers. The combining efficiency estimated by comparing the output of all optimized lasers was as high as $95.2 \%$. As the resulting combined beam has linear polarization, the approach can be applied for combining a desirable number of fibre lasers.
\end{abstract}

Keywords: fibre lasers, fibre optics, laser beam combining, laser resonators

PACS: 42.55.Wd, 42.81.Qb, 42.60.Pk

\section{Introduction}

Coherent addition of several low-power lasers, each with a high beam quality, can lead to a laser source of high brightness. This is particularly applicable to fibre lasers. Due to high radiation intensities inside a fibre, optical breakdown and nonlinearities are limiting the power extractable from a single fibre laser. A convenient approach to coherent addition of fibre lasers is based on the use of a multi-arm resonator in an interferometer configuration [1-10]. The coherent combining takes place due to self-organization in laser generation that ensures amplification of resonator modes with the lowest losses. Michelson and Mach-Zehnder type resonators have been successfully used to reach nearly $100 \%$ combining efficiency of two fibre lasers. Coupling was obtained when two amplifying fibres shared a common output mirror located on one port of a standard 50/50 coupler which mixed both optical beams [1-9]. When beams of the two input ports of the beam splitter had the correctly fixed relative phase, they interfered constructively at the output port. The resultant laser beam was transmitted through the beam splitter without any loss, and coherent locking of both lasers was thus achieved. The main disadvantage of the Michelson coherent locking scheme is related to the beam splitter ratios being fixed upon fabrication, and hence any deviation of the power ratio of the two arms from the designed value results in an effective intra-cavity loss. Another approach of coherent locking of orthogonally polarized solid state lasers with a highly imbalanced power ratio was demonstrated by Phua and Lim [11]. In this case, no direct interference was involved, since the coherent locking involved orthogonal polarizations. The two orthogonal polarizations were locked coherently to produce a resultant polarization state that experienced minimal cavity losses.

In this experimental work we coherently added two orthogonally polarized fibre lasers. For optimizations of fibre lasers, we realized an adjustable output coupler that permitted precise feedback adjustment for the coherently added fibre lasers.

\section{Experiment}

The scheme of the coherent polarization locking of fibre lasers is shown in Fig. 1. An amplifying medium was a single-mode, polarization-maintaining, 


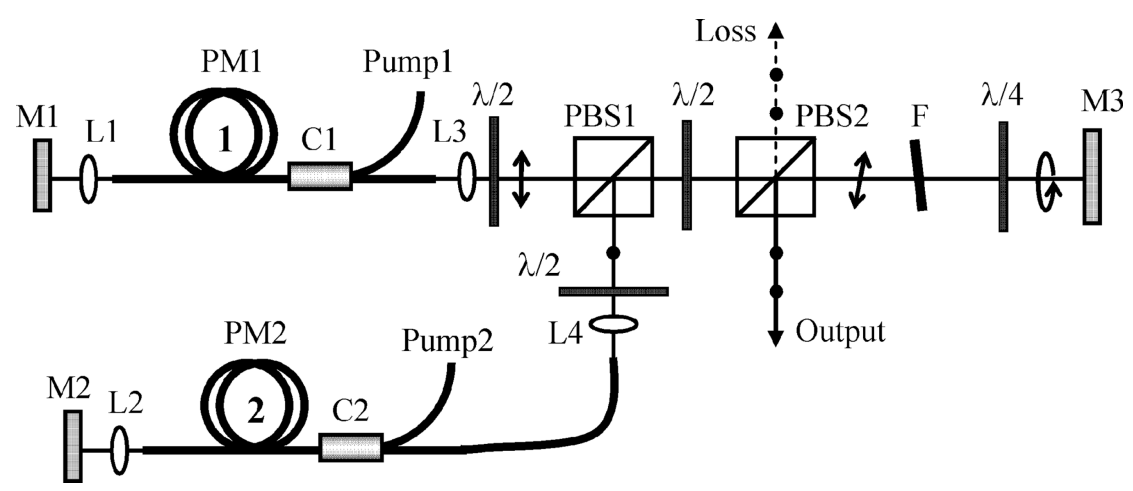

Fig. 1. Experimental set-up for coherent addition of two orthogonally polarized fibre lasers. $M 1, M 2, M 3$ are high reflecting mirrors; $L 1, L 2$, L3, L4 are collimating lenses; PM1, PM2 are polarization-maintaining single-mode ytterbium-doped fibres (PM-YSF-LO, Nufern); $\lambda / 2$ is a half wave plate; $\lambda / 4$ is a quarter wave plate; $F$ is a band pass filter; $C 1, C 2$ are pump signal combiners; $P B S 1, P B S 2$ are polarizing beam splitters.

ytterbium-doped fibre (PM-YSF-LO, Nufern). The fibre length of the first fibre laser was 4 metres and 10 metres of the second fibre laser. The fibres-end faces were angle-cleaved at 8 degrees to avoid back reflections. The pump power of the first and second fibre lasers was 90 and $100 \mathrm{~mW}$, respectively. Parameters of the fibre lasers as well as their output power in two different regimes are presented in Table 1.

The $\lambda / 2$-plates at the output of the lasers were used to adjust a proper polarization orientation. Polarization of the first laser was selected of the $p$-type (laser beam propagated through the polarizing beam splitter $P B S 1$ ). Polarization of the second laser was of the $s$-type (beam was reflected from $P B S 1$ ). In the case of equal output power of both lasers and phases, the resultant polarization at the output of $P B S 1$ was linear and orientated at 45 degrees. By means of the $\lambda / 2$-plate installed between polarizing beam splitters $P B S 1$ and $P B S 2$, polarization of the combined beam was changed to the $p$-type, and the beam propagated loosely through $P B S 2$. A fraction of radiation was coupled back to the lasers by reflecting from the back mirror and passing two times through a $\lambda / 4$-plate.

An adjustable output coupler was realized by using $P B S 2$, the $\lambda / 4$-plate, and the high reflecting mirror $M 3$. Operation of the adjustable output couplers is the following. The linearly polarized beam passing through the $\lambda / 4$-plate is transformed into the elliptically polar-

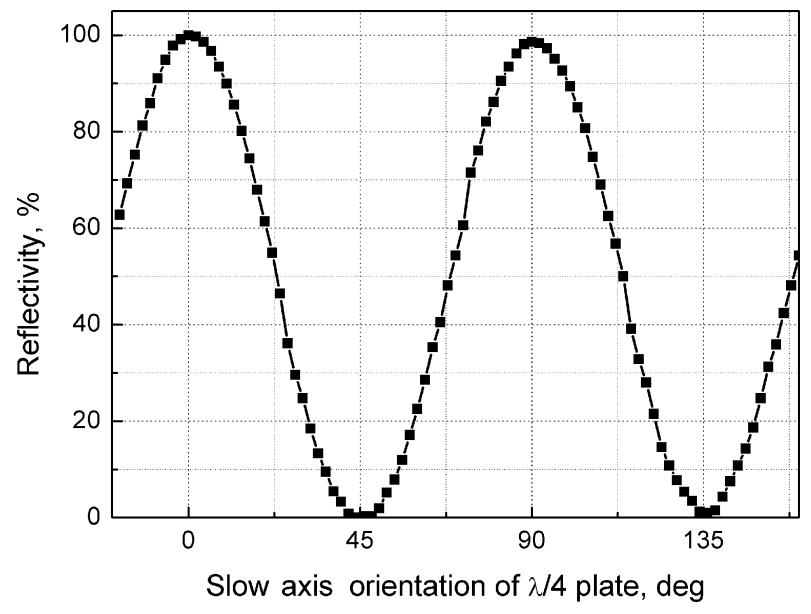

Fig. 2. Reflectivity of the adjustable output coupler depending on the relative orientation of $\lambda / 4$-wave plate (experiment).

ized beam. By reflecting from the high reflecting mirror $M 3$ the polarization of the beam changes its direction to opposite and, passing the second time through the $\lambda / 4$ plate, the beam is transformed back into the linearly polarized one, but the direction of polarization is rotated by 90 degrees. One component of polarization ( $s$-type) is coupled out of the cavity by reflecting from $P B S 2$, while the other orthogonal component of polarization ( $p$-type) is coupled back to the lasers. By rotating slow axis of the $\lambda / 4$-wave plate from 0 to 45 degrees, the reflection of the output coupler can be adjusted from 0 to $100 \%$ as is shown in Fig. 2.

Table 1. Technical and output parameters of fibre lasers used in the experiments on coherent addition.

\begin{tabular}{ccccc}
\hline Laser & $\begin{array}{c}\text { Active fibre } \\
\text { length, } \mathrm{m}\end{array}$ & $\begin{array}{c}\text { Pump power, } \\
\mathrm{mW} \text { @ 976 nm }\end{array}$ & $\begin{array}{c}\text { Output power } \\
\text { at optimized } \\
\text { coupling, mW }\end{array}$ & $\begin{array}{c}\text { Output power } \\
\text { at optimized } \\
\text { combining, mW }\end{array}$ \\
\hline$\# 1$ & 4 & 90 & 17 & 17 \\
$\# 2$ & 10 & 100 & 45 & 42 \\
\hline
\end{tabular}




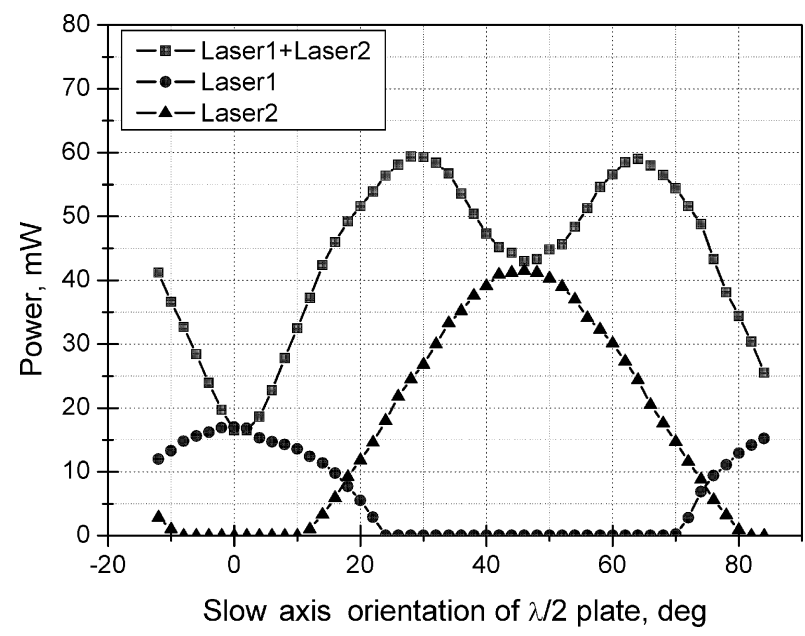

Fig. 3. Variation in output power of the first, second, and coherently added fibre lasers with the orientation of the $\lambda / 2$-plate placed between polarization beam splitters $P B S 1$ and $P B S 2$. Selection of the lasers in the experiment was done by switching on and off the pump power of one of the lasers. The combined output power was measured with the pump power of both lasers switched on.

\section{Results and discussion}

Two orthogonally polarized fibre lasers were locked in phase in such a way that the combined beam was linearly polarized after passing the polarizing beam splitter $P B S 1$ and orientation of polarization was determined by the power ratio of the lasers. By adjusting a slow axis of the half-wave plate $(\lambda / 2)$ installed between polarizing beam splitters $P B S 1$ and $P B S 2$, the beams of both lasers with different polarizations were coupled into a single $p$-polarized beam that experienced no loss passing through the polarizing beam splitter $P B S 2$.

Both lasers were optimized by adjusting the output coupler to achieve the highest output power in a combined beam. In order to estimate a combining efficiency, the output power of separate lasers was measured, keeping the adjustment of the output coupler under optimized combining conditions. The pump diodes were switched on for both lasers separately and the output power of both fibre lasers in 'free-running' (notlocked) regime was measured. The maximum output power for the first laser was $17 \mathrm{~mW}$ and $42 \mathrm{~mW}$ for the second laser. The maximum power for the first and second fibre lasers was measured when orientation of slow axis of the $\lambda / 2$-plate was at 0 degrees and 45 degrees, respectively. The output power of the combined beam was measured when both lasers were pumped at settled power and orientation of the $\lambda / 2$-plate was adjusted. The highest output power of the coherently locked fibre lasers was $59 \mathrm{~mW}$. Figure 3 shows variation in the output power of the first, second, and coherently locked lasers with rotation of the $\lambda / 2$ - plate.
When one of the lasers was generating at the maximum power relative to the $\lambda / 2$-plate orientation, the other laser was not generating at all. The maximal output power of the coherently locked fibre lasers was achieved when relative orientation of the slow axis of the $\lambda / 2$ - plate was $29^{\circ}, 119^{\circ}, 209^{\circ}, \ldots$ and $63^{\circ}, 153^{\circ}$, $243^{\circ}, \ldots$ (adding multiple of $90^{\circ}$ ). It is interesting to note that the maximum output in the combined beam was achieved at orientation of the $\lambda / 2$-plate when the first laser alone was not generating. The slow axis orientation of the $\lambda / 2$-plate in respect of the power ratio $x$ of the lasers can be expressed by relation [11]:

$$
\theta_{\lambda / 2}=\left\{\begin{array}{c}
\frac{\arctan \sqrt{x}}{2}+n \frac{\pi}{2}, \\
-\frac{\arctan \sqrt{x}}{2}+(n+1) \frac{\pi}{2},
\end{array}\right.
$$

where $\theta_{\lambda / 2}$ is the slow axis orientation of the $\lambda / 2$-plate, which is inserted between PBS1 and PBS2, $x$ is the power ratio of the lasers, and $n$ is an integer number. Two solutions in (1) correspond to two maxima in the output power of the coherently added fibre lasers with the orientation of the $\lambda / 2$-plate. In contrast to [11] both maxima of the output power of the coherently added fibre lasers were equal in magnitude (Fig. 3).

By comparing the output power of the free running and coherently locked lasers it was observed that the combining efficiency exceeded $100 \%$, keeping the wave plates' orientation fixed. The enhancement was assumed to be due to difference in optimal feedback conditions for both free running lasers. With the common output coupler, one laser was capable of seeding additionally the second laser. The extra-seeded laser generated the additional power.

Additional experiments were conducted to prove the concept. Each fibre laser was individually optimized by adjusting the output coupler (rotating the $\lambda / 4$-plate). When the slow axis of the $\lambda / 4$-plate was set to $0^{\circ}$, then the whole radiation was coupled back to the fibre laser and the output power was equal to zero. When the slow axis of the $\lambda / 4$-plate was set to $45^{\circ}$, the whole radiation was reflected out of the resonator and due to the absence of any feedback no generation of the laser was observed. Rotation of the $\lambda / 4$-plate varied the reflection coefficient of the compound output coupler. Figure 4 shows variation in the output power of the first and second lasers by adjusting the output coupler reflection. The maximum output power of the first and second lasers was achieved when reflection of the output coupler was 17 and 14\%, respectively. Optimizing back reflection of 


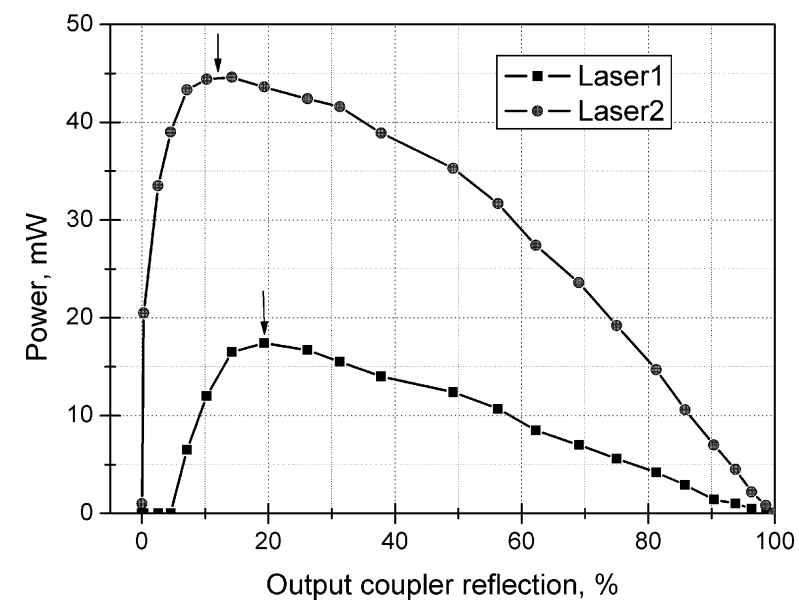

Fig. 4. Output power of the first and second fibre lasers as a function of the output coupler reflection. Reflection of the output coupler was tuned by rotation of the $\lambda / 4$-plate. When reflection is $0 \%$, there is no feedback to the cavity and whole radiation comes out. $100 \%$ means the fully closed cavity without any output. Optimal output coupler reflection is different for both lasers (marked by arrows).

the output coupler for each laser individually, the total output power of $62 \mathrm{~mW}$ was achieved, and it was higher compared with the output power of $59 \mathrm{~mW}$, in the case of both coherently locked fibre lasers. Based on those results the combining efficiency can be assumed as high as $95.2 \%$.

A high combining efficiency can be easily achieved by the method used in this research in contrast to the Michelson coherent locking method. A fundamental limit of the Michelson coherent locking scheme [1] is related to the beam splitter ratio being fixed upon fabrication, and hence any deviation of the power ratio of the two arms from the designed value will result in an effective intra-cavity loss. For example, in case of a $50 / 50$ beam splitter, the combining efficiency can be expressed as

$$
\eta_{M}=\frac{1}{2}+\frac{\sqrt{x}}{1+x},
$$

where $x$ is the power ratio of two free running fibre lasers. Hence, the power ratio of approximately 1:5 limits the combination efficiency to at most $87 \%$.

Polarizing optics (wave plates and polarizing beam splitters) used in the experiment were designed for the $1064 \mathrm{~nm}$ wavelength, but the emission maximum of the ytterbium doped fibre is at the $1030 \mathrm{~nm}$ wavelength. The band-pass filter $F$ was used to adjust the central wavelength of radiation. The central wavelength of the used filter was $1064 \mathrm{~nm}$ and the bandwidth was $10 \mathrm{~nm}$. Without the filter $F$, lasers tended to generate at the $1030 \mathrm{~nm}$ wavelength and the combining efficiency decreased a little. Figure 5 shows the radiation

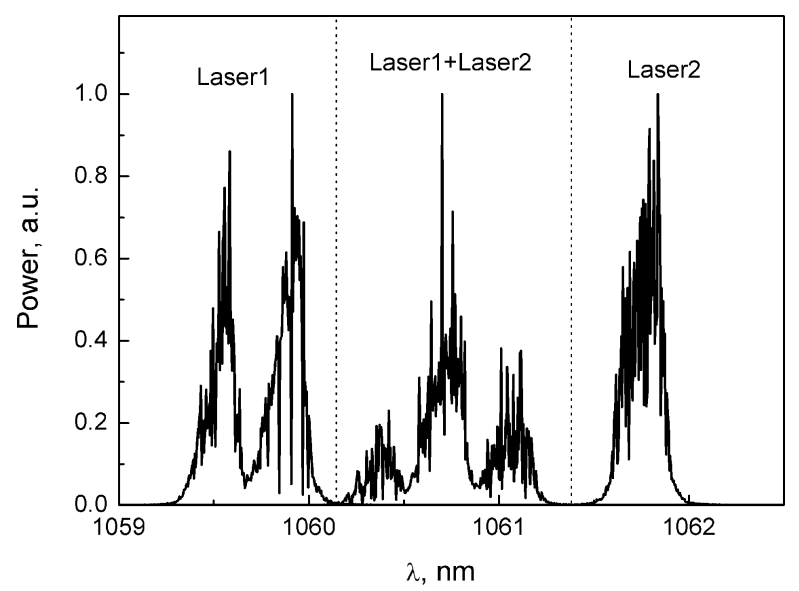

Fig. 5. Radiation spectra of the first (left), second (right), and coherently added (centre) fibre lasers.
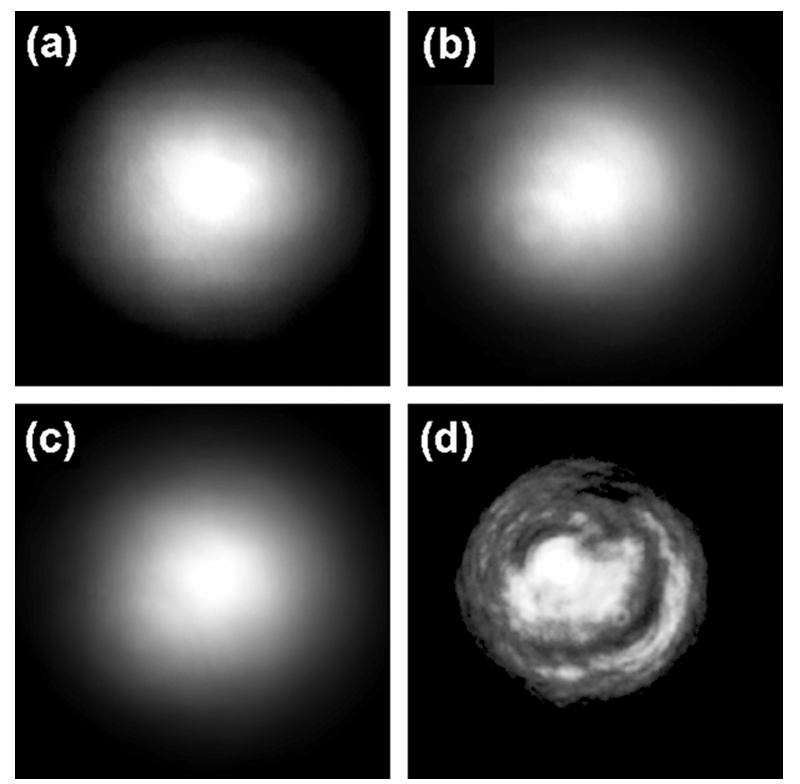

Fig. 6. Intensity distribution in output beam of (a) first laser, (b) second laser, (c) coherently added lasers, and (d) loss branch. Power in the loss branch was less than $1 \%$ compared to the output power. Interference rings can be observed in the loss branch.

spectra of the first, second, and coherently-locked fibre lasers. The spectrum of the coherently-locked lasers was distributed between the spectra of the first and second free-running fibre lasers. The spectrum instability of the coherently-locked and free-running lasers was observed. Despite the spectrum instability the output power of the combined beam remained stable.

Figure 6 shows the output beam intensity distribution of the first, second, and coherently-added fibre lasers. The beam quality of the combined beam was high and did not experience degradation compared with the freerunning lasers. Figure 6(d) presents the intensity distribution in the loss branch. The optical power in the loss branch was only a fraction of percent in comparison 


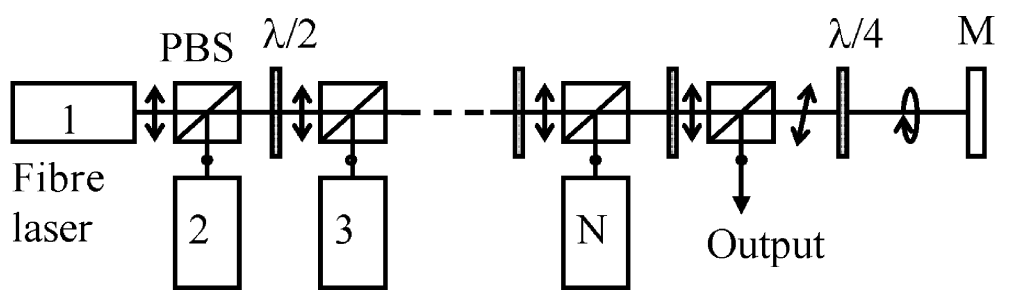

Fig. 7. Linear scheme for coherent combining of fibre lasers using polarizing optical components. Each new laser beam is added after its reflection from a polarizing beam splitter.

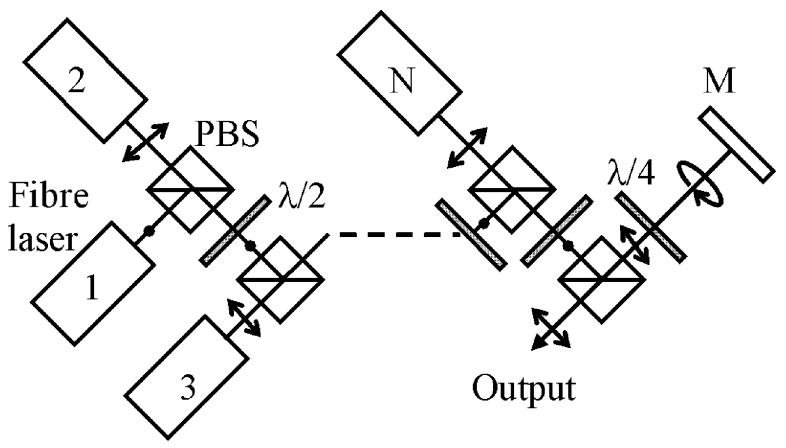

Fig. 8. Scheme for coherent combining of fibre lasers using polarizing optical components. Each new laser beam is added after its passing through a polarizing beam splitter.

with the total output power of the lasers. Power in the loss branch should be minimized in order to achieve the highest combining efficiency. Propagation directions, diameters, and divergences of the lasing modes in both lasers were aligned precisely and destructive interference of the beams in the loss branch took place. Bright interference fringes or interference rings were observed in the loss branch in the case of incorrectly matched parameters of the beams.

As the resulting combined beam has linear polarization, cascading of the coherent combining can be applied to a desirable number of fibre lasers. We propose a few multi-laser combining approaches utilizing polarization components in linear and 'tree-like' schemes.

In the scheme shown in Fig. 7, each new laser beam is added after its reflection from a polarizing beam splitter. The combined beam is of $p$-polarization and passes all PBSs without losses. The number of polarization beam splitters is equal to the number of combined lasers. A similar linear scheme was proposed for solid-state lasers in [11].

In the scheme shown in Fig. 8, each new laser beam is added after its transmission through a polarizing beam splitter. The combined beam is of $s$-polarization and propagates reflecting in all PBSs without losses.

Combining of laser beams is possible in pairs as shown in Fig. 9. In this scheme, every laser beam passes through PBS and is reflected from PBS the same number of times. As every optical component introduces

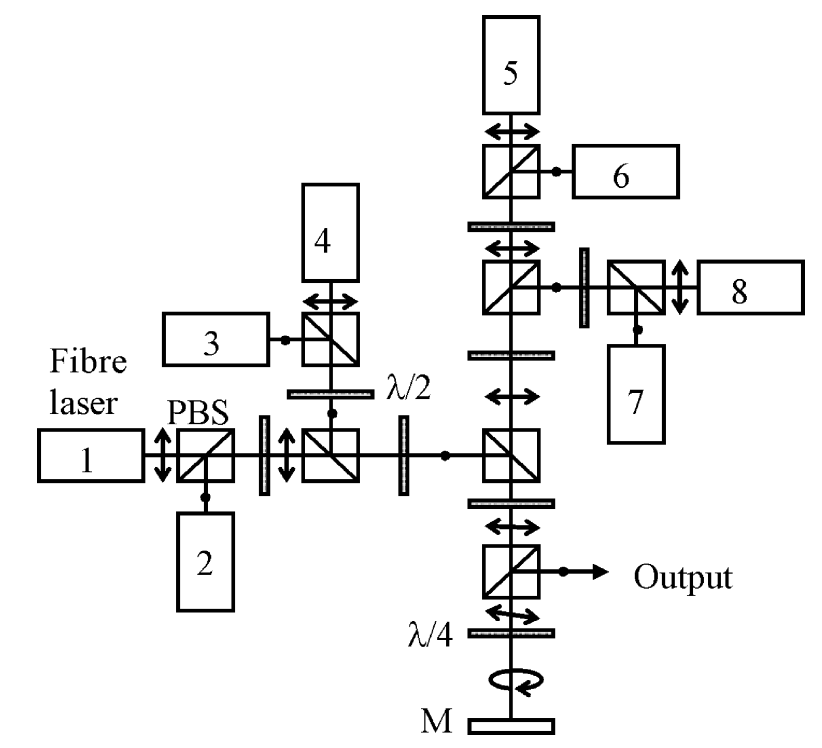

Fig. 9. Scheme for coherent combining of fibre lasers in pairs. New laser beams are initially combined in pairs with a polarizing beam splitter and added to a common beam.

optical losses, the scheme is most appropriate for combining a large number of lasers. Higher combining efficiency can be achieved by minimizing the optical path for every laser beam in the scheme. Unified combining module consisting of the polarizing beam splitter and $\lambda / 2$-plate with pig-tailed fibres can be used in the scheme.

The addition of lasers reduces the number of longitudinal modes in the output beam. The more lasers are combined, the smaller is the number of longitudinal modes in the output. The estimates show that the number of output modes reduces exponentially with the number of lasers combined [12]. Of order of 8 lasers can be efficiently combined. The future increase of number of combined lasers requires the exponential growth of the spectral bandwidth of gain and/or length of fibre lasers. The following increase of the amount of lasers combined requires the artificial adjustment of at least one of resonant frequencies of each partial laser to some common frequency. 


\section{Conclusion}

A high combining efficiency of the fibre laser beams was achieved. Comparing the output power of both free-running fibre lasers with the output power in coherently locked state it was observed that the combining efficiency exceeded $100 \%$. The output power enhancement was due to difference in optimal feedback conditions for separate free-running lasers. One laser was additionally seeded from the second laser, and the seeding originated the higher output power of the coherently added lasers. The combining efficiency estimated by comparing the output of all separately optimized lasers was as high as $95.2 \%$. As the resulting combined beam has linear polarization, the approach can be applied for combining a desirable number of the fibre lasers.

\section{Acknowledgements}

The work was supported by the Lithuanian State Science and Studies Foundation under project No B12/2008 (SKAIZERIS). K. Regelskis acknowledges the Lithuanian Research Council for the post-doc grant support under project No MOS-1/2010 (GARLAMA).

\section{References}

[1] D. Sabourdy, V. Kermene, A. Desfarges-Berthelemot, L. Lefort, and A. Barthelemy, Opt. Express 11(2), 8797 (2003).

[2] A.A. Ishaaya, L. Shimshi, N. Davidson, and A.A. Friesem, Opt. Express 12(20), 4929-4934 (2004).

[3] T.B. Simpson, F. Doft, P.R. Peterson, and A. Gavrielides, Opt. Express 15(18), 11731-11740 (2007).

[4] A. Shirakawa, T. Saitou, T. Sekiguchi, and K. Ueda, Opt. Express 10(21), 1167-1172 (2002).

[5] V.A. Kozlov, J. Hernandez-Cordero, and T.F. Morse, Opt. Lett. 24(24), 1814-1816 (1999).

[6] S.-P. Chen, Y.-G. Li, and K.-C. Lu, Opt. Express 13(20), 7878-7883 (2005).

[7] V. Eckhouse, A.A. Ishaaya, L. Shimshi, N. Davidson, and A.A. Friesem, Opt. Lett. 31(3), 350-352 (2006).

[8] M. Fridman, V. Eckhouse, N. Davidson, and A.A. Friesem, Opt. Lett. 32(7), 790-792 (2007).

[9] Q. Peng, Z. Sun, Y. Chen, L. Guo, Y. Bo, X. Yang, and Z. Xu, Opt. Lett. 30(12), 1485-1487 (2005).

[10] J. Lhermite, A. Desfarges-Berthelemot, V. Kermene, and A. Barthelemy, Opt. Lett. 32(13), 1842-1844 (2007).

[11] P.B. Phua and Yuan Liang Lim, Opt. Lett. 31(14), 2148-2150 (2006).

[12] D. Kouznetsov, J.F. Bisson, A. Shirakawa, and K. Ueda, Opt. Rev. 12(6), 445-447 (2005).

\title{
DIDELIO NAŠUMO KOHERENTINIS STATMENŲ POLIARIZACIJŲ SKAIDULINIŲ LAZERIŲ SPINDULIUOTĖS SUJUNGIMAS
}

\author{
K. Regelskis, N. Gavrilinas, R. Trusovas, G. Račiukaitis \\ Fiziniu ir technologijos mokslu centro Fizikos institutas, Vilnius, Lietuva
}

\begin{abstract}
Santrauka
Skaidulinių lazerių pluoštų koherentinis sujungimas yra vienas perspektyviausių būdų, siekiant padidinti spinduliuotès galias, išlaikant lazeriu spinduliuotès koherentiškumo savybes. Dauguma koherentinių sujungimo būdų yra pagrịsti lazerių modų sinchronizavimu, panaudojant interferencinius metodus, kuomet interferuoja vienodų poliarizacijų pluoštai. Kitas koherentinio sujungimo būdas yra statmenai poliarizuotų lazerių modų sinchronizacija.

Statmenu poliarizacijų skaiduliniai lazeriai buvo sinchronizuojami, panaudojant poliarizacinį pluošto daliklį PBS1 (1 pav.). Jeigu abieju pluoštu fazès sutampa, sujungtos spinduliuotès poliarizacija yra tiesinè, o orientacija priklauso nuo lazeriu galių santykio. Pusès bangos ilgio plokštele $(\lambda / 2)$ spinduliuotès poliarizacija buvo orientuojama taip, kad pluoštas be nuostoliu galètu sklisti per toliau esanti poliarizacini pluošto daliklị $P B S 2$. Derinamo atspindžio išvadinis veidrodis buvo sudarytas iš $P B S 2$, ketvirčio bangos
\end{abstract}

ilgio plokštelès $\lambda / 4$ ir veidrodžio $M 3.3$ paveikslèlyje pavaizduota pirmo, antro ir koherentiškai sinchronizuotų lazerių išvadinių galių priklausomybė nuo $\lambda / 2$ plokštelès, esančios tarp $P B S 1$ ir $P B S 2$, pasukimo kampo. Lyginant koherentiškai sinchronizuotu ir savarankiškai veikiančiu lazerių galias nustatyta, kad sujungimo našumas viršija $100 \%$. Kadangi sujungimo našumas negali viršyti $100 \%$, tai manoma, kad veikiant vienam lazeriui, grižtamasis ryšys buvo šiek tiek per mažas. Pirmas lazeris, veikdamas kartu su antru lazeriu, gauna papildomo stimulo iš kito lazerio ir tokiu būdu koherentiškai sinchronizuoti lazeriai generuoja didesnes galias nei abu savarankiškai veikiantys lazeriai. Lyginant atskirai optimizuotų lazerių išvadines galias (atskirai optimizavus išvadinį veidrodị), sujungimo našumas siekè $95,2 \%$. Kadangi sujungtos spinduliuotès poliarizacija yra tiesinè, metodas leidžia kombinuoti didesnį kiekį skaidulinių lazerių. Pateiktos galimos daugelio lazerių sujungimo schemos. 